\title{
A STUDY OF HAEMOGLOBIN PATTERNS AMONG THE STUDENTS OF RIMS
}

\author{
Urmila Thiyam ${ }^{1}$, Sunita Haobam², Y. Mohen Singh ${ }^{3}$, Durlav Chandra Sharma ${ }^{4}$
}

\begin{abstract}
${ }^{1}$ Assistant Professor, Department of Pathology, Jawaharlal Nehru Institute of Medical Sciences. ${ }^{2}$ Assistant Professor, Department of Pathology, Jawaharlal Nehru Institute of Medical Sciences. ${ }^{3}$ Professor, Department of Pathology, Jawaharlal Nehru Institute of Medical Sciences. ${ }^{4}$ Professor, Department of Pathology, Jawaharlal Nehru Institute of Medical Sciences.
\end{abstract}

ABSTRACT: Haemoglobinopathies are a major health problem worldwide. Because of the high prevalence of these disorders in India and especially in North-East, we undertook this limited student based study as RIMS comprised students from the seven North-East states of Arunachal Pradesh, Manipur, Meghalaya, Mizoram, Nagaland, Sikkim and Tripura.

AIMS: To study the prevalence of haemoglobin variants among the North-East students of RIMS and to find out any abnormal haemoglobin pattern pertaining to a particular community.

MATERIAL AND METHODS: The present study was carried out in the Department of Pathology, RIMS. From Sept. 2002 to Dec. 2004, our study included 100 student volunteers taking a minimum of ten from each of the seven states. History of presenting complaints, personal, family and past illness were taken. Physical examination was done with special emphasis on appearance, presence of pallor, jaundice and hepatosplenomegaly etc. Blood samples were collected in 2 EDTA vials, one was used for CBC and another for preparation of hemolysate. CBC was done for all cases by electronic cell counter supported by manual hemocytometry, peripheral blood examination and reticulocyte count. All the cases were routinely screened for haemoglobin type using standard alkaline cellulose acetate electrophoresis with Tris-Ethylene Diamine Tetra Acetic Acid (EDTA) borate buffer. Fetal Hb. estimation, sickling test, serum bilirubin estimation were also done in relevant cases.

RESULTS: Out of the 100 student volunteers studied, 98 cases showed HbA pattern in 46 males and 52 females while HbE was seen in 2 cases, 1 male and a female. The prevalence of $\mathrm{HbE}$ was $2 \%$ in our study, which belonged to the ethnic group of Garo of Meghalaya. Both case had mild anemia with microcytosis and normal reticulocyte count. Peripheral smear showed anisopoikilocytosis and target cells. RBC count, MCH values were within normal range.

CONCLUSION: Our study showed that HbA was the predominant haemoglobin type amongst the North-East students of RIMS. HbE was also prevalent amongst these students and common among the mongoloid group of Garo with an incidence of $2 \%$. As this study is limited student volunteer based, it cannot represent any community/population. It emphasises the need for further studies with a larger sample involving many communities of different ethnic groups to support the above findings before drawing a conclusion.

KEYWORDS: Haemoglobinopathies, Electrophoresis, Haemoglobin Electrophoretic Pattern.

HOW TO CITE THIS ARTICLE: Urmila Thiyam, Sunita Haobam, Y. Mohen Singh, Durlav Chandra Sharma. "A Study of Haemoglobin Patterns Among the Students of RIMS." Journal of Evolution of Medical and Dental Sciences 2015; Vol. 4, Issue 94, November 23; Page: 15979-15981, DOI: $10.14260 /$ jemds/2015/2329.

INTRODUCTION: Haemoglobinopathies are the commonest genetic defect worldwide with an estimated 269 million carriers. ${ }^{1}$ It is anticipated that the global economic burden of haemoglobinopathies on public health will increase over the coming decades. ${ }^{2}$ Studies on haemoglobinopathies have been carried out in different parts of the world as well as in India. Considering the high prevalence of abnormal haemoglobins and thalassemia in North-East India, it is desirable to evaluate the haemoglobin patterns amongst the students of Regional Institute of Medical Sciences (RIMS), Imphal, Manipur, as RIMS comprises students from seven North Eastern states of Arunachal Pradesh, Manipur, Meghalaya, Mizoram, Nagaland, Tripura and Sikkim.

Although, many diagnostic methods are available for identification of haemoglobinopathies,

Financial or Other, Competing Interest: None.

Submission 03-11-2015, Peer Review 04-11-2015,

Acceptance 13-11-2015, Published 23-11-2015.

Corresponding Author:

Dr. Urmila Thiyam,

Singjamei Mayengbam Leikai,

Imphal-795008,

Manipur.

E-mail: urmilath2014@gmail.com

DOI:10.14260/jemds/2015/2329. electrophoresis of haemolysates remains the technique of choice and is most commonly employed. In this study, the results of electrophoresis of haemolysates are analysed and the prevalence of different haemoglobin patterns amongst the North-East students of RIMS are observed.

MATERIALS AND METHODS: The study was carried out in the Department of Pathology, RIMS, Imphal, Manipur from September 2002 to December 2004. A total number of 100 students were studied, randomly taking a minimum of ten students each from each of the seven North-East states: Arunachal Pradesh, Manipur, Meghalaya, Mizoram, Nagaland, Sikkim and Tripura. Student volunteers belonging to different ethnic groups were investigated according to a predesigned proforma. The number of state wise volunteers were as follows. Arunachal Pradesh- 11, Manipur- 32, Meghalaya- 10, Mizoram- 11, Nagaland- 12, Tripura- 14, Sikkim- 10. A detailed history of each volunteer was taken regarding any presenting complaints, personal history, past history and family history. A detailed physical examination was done with special emphasis on the appearance, presence of pallor, jaundice, hepatosplenomegaly, etc. 
PROCEDURE: A $4 \mathrm{ml}$ of venous blood was collected from the antecubital vein in 2 vials. One vial was used for complete hemogram and another for hemolysate preparation. Complete hemogram was done for all cases by electronic cell counter (MSQ haematology cell counter, Cergy Pontois, France), supported by manual hemocytometry and peripheral blood examination (Leishmain stain) RBC morphology regarding presence of hypochromia, microcytosis, anisocytosis, poikilocytosis, sickle cells, target cells, polychromasia, basophilic stippling and other inclusion bodies were also assessed.

All the volunteers were routinely screened for the haemoglobin types using cellulose acetate electrophoresis at alkaline $\mathrm{pH}$ (pH 8.4-8.6). A small quantity of haemolysate was placed on a cellulose acetate membrane and carefully introduced into the electrophoretic tank containing TrisEDTA-borate buffer. Electrophoretic separation was allowed to operate for 45 to 60 minutes at an electromotive force of 160 volts (150-200 volts). The strips were then stained with Ponceau $S$ and read immediately. Haemolysates from blood samples of known haemoglobin (AA, EE) were run as control. Fetal haemoglobin estimation and serum bilirubin estimation were also done in relevant cases. $\mathrm{Hb} \mathrm{F}$ estimation was done by alkali denaturation test (Modified Betke Method).

Identification of normal and abnormal haemoglobins were generally made from their relative mobility and position of the bands compared to known samples. Corroboration with other haematological findings such as $\mathrm{Hb} \mathrm{F}$ estimation, inclusion body test for $\mathrm{HbH}$ were helpful. A consideration of the geographical area and other ethnic background of the subject should always be made for judicious interpretation of an abnormal haemoglobin.
RESULTS AND OBSERVATION: The study included 53 females and 47 males. The age range was 18 to 44 years, the largest number of study group belonged to 21 to 30 years of age group comprising 55\% (Table 1). Out of the 100 cases screened for $\mathrm{Hb}$ type, 98 cases showed $\mathrm{HbA}$ pattern including 46 males and 52 females. Two cases showed showed $\mathrm{Hb} \mathrm{E}$ pattern including 1 male and 1 female. (Table 2) Fig. 1 shows the mobility pattern of $\mathrm{Hb} \mathrm{A}$ and $\mathrm{Hb} \mathrm{E}$ on cellulose acetate electrophoresis. Both the cases of $\mathrm{HbE}$ were from the state of Meghalaya Garos. (One of which was asymptomatic and the other presented with jaundice and splenomegaly).

Both had mild anaemia with microcytosis with a mean $\mathrm{Hb}$ concentration of $11.5 \mathrm{gm} / \mathrm{dl}$, the reticulocyte counts were within normal range. Peripheral blood smears showed aniopoikilocytosis and target cells. RBC count and MCHC values were within normal range.

\begin{tabular}{|c|c|c|c|c|}
\hline Age (Years) & Male & Female & Total & Percentage \\
\hline $18-20$ & 7 & 16 & 23 & $23 \%$ \\
\hline $21-30$ & 27 & 28 & 55 & $55 \%$ \\
\hline $31-40$ & 12 & 8 & 20 & $20 \%$ \\
\hline $41-50$ & 1 & 1 & 2 & $2 \%$ \\
\hline Total & 47 & 53 & 100 & 100 \\
\hline \multicolumn{7}{|r|}{ Table 1: Distribution of Cases According to Age and Sex } \\
\hline
\end{tabular}

\begin{tabular}{|c|c|c|c|c|}
\hline Hb Pattern & Male & Female & Total & Percentage \\
\hline $\mathrm{Hb} \mathrm{AA}$ & 46 & 52 & 98 & $98 \%$ \\
\hline $\mathrm{Hb} \mathrm{EE}$ & 1 & 1 & 2 & $2 \%$ \\
\hline TOTAL & $\mathbf{4 7}$ & $\mathbf{5 3}$ & $\mathbf{1 0 0}$ & $\mathbf{1 0 0} \%$ \\
\hline Table 2: Distribution of Cases showing the \\
Hb Pattern on Cellulose Acetate Electrophoresis \\
\hline
\end{tabular}

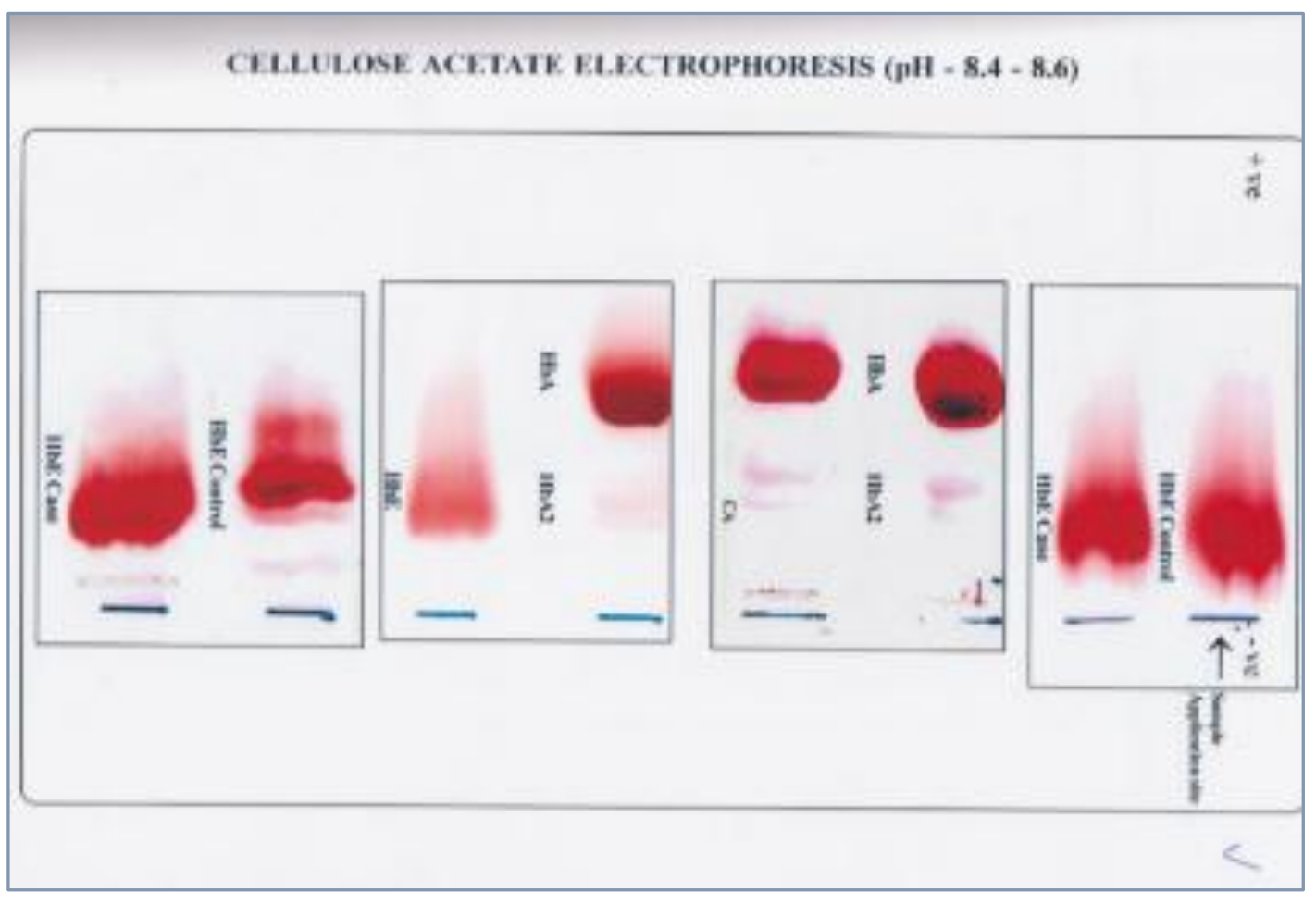

Fig. 1: Shows the Mobility Pattern of HBE and HBA on Cellulose Acetate Electrophoresis 
Biochemical Analysis: Increased bilirubin was observed in the second male case with a total bilirubin of $3.6 \mathrm{mg} \%$. Direct bilirubin was $0.5 \mathrm{mg} \%$. Indirect bilirubin was $3.1 \mathrm{mg} \%$. The serum bilirubin in the first female case was normal.

$1^{\text {st }}$ case showed $1 \% \mathrm{Hb} \mathrm{F}$, while the $2^{\text {nd }}$ case showed $2 \% \mathrm{Hb} \mathrm{F}$.

DISCUSSION: The occurrence of haemoglobinopathies is worldwide, but there is considerable difference in the recorded prevalences in different geographic areas and different ethnic groups. The cummulative gene frequency of haemoglobinopathies in India is $4.2 \%{ }^{3}$ Lehmann $\mathrm{H}$ et al. ${ }^{4}$ demonstratied that the gene disorder was very common in North East region of India where the population comprise many races and tribes.

In the present study, we analysed 100 student volunteers belonging to different ethnic groups of the seven different states of North East India. We observed that $\mathrm{Hb} \mathrm{A}$ was the predominant haemoglobin type. $\mathrm{Hb} \mathrm{E}$ was detected in two Garo students out of a total of 10 students from the state of Meghalaya. Other $\mathrm{Hb}$ types were not detected. Das et $\mathrm{al}^{5}$ observed that in seven different areas of Assam, the highest prevalence of $\mathrm{HbE}$ gene disorder was among the TibetoBurman speakers groups of Kacharis, Garos, Rabhas, Lalungs, Rajbanshis. They gave a prevalence range of $\mathrm{HbAE}, 37 \%$ to $52 \%$ and $\mathrm{Hb}$ EE, 15 to $31 \%$.

In our observations, we noted that the overall incidence of $\mathrm{HbE}$ in the North-Eastern region was $2 \%$. This was in sharp contrast to the observations made by Balgir RS. ${ }^{6} \mathrm{He}$ reported an average frequency of $10.9 \%$ of $\mathrm{HbE}$ gene disorder in North Eastern region of India.

The difference might be because in his studies he included the population of Assam, which showed a high incidence of $29.7 \%$ and West Bengal where a $7 \%$ frequency was reported. These 2 groups were not included in our study.

In the present study, $\mathrm{Hb} \mathrm{E}$ was not detected among the volunteers from the states of Arunachal Pradesh, Manipur, Mizoram, Nagaland, Sikkim and Tripura. The findings were in sharp contrast to the observations made by Balgir RS. ${ }^{6} \mathrm{He}$ reported an incidence of $8.3 \%$ in Arunachal Pradesh, $6.7 \%$ in Manipur, $3.5 \%$ in Nagaland and $0.7 \%$ in Sikkim. The difference might be due to smaller number of cases studied within a very short time.

In our study, we observed that one case was asymptomatic and enjoyed apparent good health.
The $2^{\text {nd }}$ case presented with jaundice and mild splenomegaly. Both had mild anemia with a mean haemoglobin concentration of $11.5 \mathrm{gm} / \mathrm{dl}$ and microcytosis. The reticulocyte count was normal. These finding were in accordance to the observations made by Piplani S. ${ }^{7} \mathrm{He}$ included 3 cases of $\mathrm{HbE}$ - thalassemia and 6 cases of $\mathrm{HbE}$ disease in his study; 2 cases were asymptomatic. Jaundice and splenomegaly were common. Mild anemia with microcytosis were present in all the cases with a mean $\mathrm{Hb}$ concentration of $11.3 \mathrm{gm} / \mathrm{dl}$, reticulocyte count and platelet count were normal which was concordant with our study.

CONCLUSION: Hb A was the predominant haemoglobin amongst the students of RIMS. Hb E was also found amongst mongoloid students of Garo with a $2 \%$ incidence rate. There was no significant age and sex differences in its distribution. $\mathrm{Hb} \mathrm{E}$ disease is usually asymptomatic, but it may also present with jaundice and splenomegaly. Mild anemia with microcytosis and normal reticulocyte count was seen in this gene disorder. Peripheral smear showed mild anisocytosis, poikilocytosis and target cells. Other haemoglobin types were not common. Further studies with a larger sample involving many communities of different ethnic groups is necessary to support the above findings before drawing a conclusion.

\section{REFERENCES:}

1. Angastiniotis M and Modell B; Global epidemiology of haemoglobin disorders. Ann N Y Acad Sci. 1998; 850:25169.

2. Weatherall DJ; the inherited diseases of haemoglobin are an emerging global health burden. Blood. 2010; 115: 4331-6.

3. Sarnaik SA; Thalassaemia and related haemoglobinopathies. Indian J Paediatr.2005; 72:314-24.

4. Lehman $H$, Story $P$ and Thein $H$; Haemoglobin $E$ in Burmese, Brit Med J. 1956; 1: 544-547.

5. Das BM Chakravarty MA Delbruck H and Flatz G; High prevalence of haemoglobin $\mathrm{E}$ in two populations of Assam. Human Genetics. 1971; 12: 264.

6. Balgir RS; Genetic epidemiology of the three predominant abnormal haemoglobin in India. J Assoc Physicians India. 1996; 44(1): 25-28.

7. Piplani S; Haemoglobin E disorders in North-East India, J Assoc Physicians India. 2000; 48(11): 1082- 1084. 